\title{
THE COUNTY COURT IN THE THIRTEENTH CENTURY.
}

The county Court, or shiremoot, may be said to be a part of that foundation of local institutions which the Normans. found in England and upon which they built their superstructure of central administration. Its existence through the reigns of William the Conqueror and William Rufus is shown by writs, addressed as in the preceding reigns, to the sheriffs and other leading members of the county. ${ }^{1}$ Whether the feudal barons had attempted to destroy this part of the judicial system or whether the sheriffs had abused it, is not known, but for some reason Henry I. felt it was necessary some time between $\mathrm{I}$ IO 8 and $\mathrm{I} I \mathrm{I} 2$ to issue an order for holding the Courts of the hundred and the shire, "as in the time of King Edward and not otherwise."2

By the Leges Henrici Primi, which Dr. Lieberman places in the period between $I 108$ and $I I I 8,{ }^{3}$ we find that the full Court met twice a year under the sheriff or his deputy and was composed ${ }^{4}$ of the "episcopi" [bishops], "comites" [earls], "vice domini" [bishops' deputies], "vicarii" [vicars], "centenarii" [hundredors], "aldermanni" [aldermen], "praefecti" [mayors], "praepositi" [reeves], "barones" [barons], "vavassores" [free tenants of tenants in chief], "tungrevii" [headmen of townships], "et ceteri terrarum domini," whoever they may have been. Summarizing what can be gathered from the meagre records of the twelfth century we may say that the pleas of the Crown were recorded in the county Court for the view of the Curia Regis. It also had some criminal jurisdiction, though its work was mainly in civil cases and in voluntary jurisdiction, such as witnessing transfers of land and sanctioning documents,

\footnotetext{
${ }^{3}$ Palgrave, Rise and Progress of the English Commonwealth, II, clxxix.

2 Stubbs, Select Charters, 103, I04.

3 Thorpe, Ancient Laws and Institutes of England, I, 497-608.

- Leges, etc., c. vii, $\$ \$ 2,6$.

- Stubbs, Constitutional History of England, I, 426. 284
} 
but definite form was given to it under the various statutes and writs of the thirteenth century.

Turning our attention to the constitution of the Court as it existed in the thirteenth century, we find that it was held by the sheriff or by knights deputized by him, ${ }^{6}$ and that in this body the suitors were the judges, the sheriff the presiding officer. It is necessary, therefore, to find out who were the suitors. Earlier writers, Palgrave, Hallam, Stubbs and others, have stated without hesitation that they were all the freeholders of the county; but Mr. Maitland ${ }^{7}$ offers a different theory, and cites very convincing evidence in its behalf. He maintains that suit to the county Court was not an incident to freehold tenure, but had, by the thirteenth century, become a burden on specific lands; that subinfeudation, though increasing the number of freeholders, did not increase the number of suitors, the burden of suit of Court being like that of scutage in that its ultimate incidence was settled by feoffor and feoffee. A whole manor, vill or tract of land, though subdivided, owed only its accustomed suit, and it was a matter for the holders to settle among themselves who should pay it. The Hundred Rolls of 1279 give much illustrative material for this theory. ${ }^{8}$ For instance, Martin Fitz Eustach ${ }^{9}$ held of the mesne land of a certain villa, two virgates, for which he returned 2s. per year and made "suit at the county and hundred for the whole villa." John of Appilfeld," holding from a certain Abbot, "did suit for the Abbot at the county and hundred Court." The burden might be divided; Roger Gunnild ${ }^{11}$ held from Thomas, in Croxton, one messuage and forty acres, for which he returned $4 \mathrm{~s}$. per year and owed one part of a suit to the county and hundred Courts, against two parts of the suit which a certain Lord Hugh owed.

The number of suits due the county was definitely fixed and the Hundred Rolls give account not only of those who

-Selden Society, Select Pleas of the Crown, P1. I06, p. 62.

'English Historical Review, July, 1888, III, 417.

Rotuli Hundredorum, I, 455, 447, 498; II, 28, 3I8, 434, 504, 508, 559, $640,656,659,701$.

Ibid., II, 488.

"Ibid., II, 499.

"Ibid., II, 509. 
owe suit but of how often they owe it. Alex of G. ${ }^{12}$ held one-half a virgate from John Fitz Nigel for 3 d. per year and did "suit to two counties and two hundreds." Robert of $\mathrm{F}^{13}$ held from the same John, but did suit at only two hundred Courts. On the other hand, Sampson Foliot, ${ }^{14}$ who held from the King in capite, owed suit to the hundred every three weeks and to the county every month, but he relieved himself of the disagreeable duty by enfeoffing Ralph of Eyford with one-half a virgate of land, "for that he is the attorney of the said Sampson in the county and the hundred." In another case we find the Aldermen ${ }^{15}$ of the Hundred doing suit to the county for the hundred, so the barons and knights were "free from suit."

The Abbot of Ramsey ${ }^{16}$ arranged for the suit of the vill of Cranfield by setting apart four virgates whose holders paid no rent to him, but did suit at the county and hundred "pro tota villata" : "Galfrid Rodland holds half a hyde of the old feoffment. But for one virgate he returns no rent to the Abbot, because it is one of the four virgates which free the whole vill from suit at the county and hundred through the year."

Mr. Maitland accounts for so seemingly capricious a distribution on the supposition that when Henry I. revived and enforced attendance upon the local Courts he included all freeholders who had no chartered or prescriptive immunity or whose overlords had none, but this duty was regarded as a burden on the land and so the number of suits was not affected to any great extent by subsequent subinfeudation. The great number of freeholders shown in the Hundred Rolls seems to make it impossible that they all owed suit ordinarily, even if it be granted that they were bound to attend the justices in eyre. His final conclusion is that the ordinary form of the county Court, the "plenus comitatus," which heard cases and delivered judgments was not an assembly of all freeholders, but only of those persons who, by means of proprietary arrangements between lords and

12 Ibid., II, 835 .

${ }^{23}$ Ibid., II, 836 .

"Ibid., II, 838.

${ }^{25}$ Ibid., II, 204.

${ }^{18}$ Cartularium Monasterii de Rameseia, I, 438, 439 (I244). 
tenants, had become bound to do that fixed amount of suit to which the county was entitled. Instead of being an assembly of all tenants in chief or all freeholders, the person who did suit and who was bound by tenure to do the suit, was sometimes a small socager holding a single virgate.

Persons were from time to time exempted from suit, by special arrangements. In I254 ${ }^{17}$ Henry III. sent a writ to the sheriff of Norfolk, withdrawing a suit from the county Court, since the parties were Barons of the Exchequer and so were exempt from such suit. ${ }^{18}$

In I259, section 4 of the Provisions of Westminster ${ }^{19}$ excused archbishops, bishops, abbots, priors, earls, barons and religious women from appearing at the sheriff's Tourn, unless their presence was especially necessary. One of the common franchises ${ }^{20}$ was the exemption of the lords' men from doing suit at the regular hundred and county Courts and the sheriff's Tourn. The multiplication of suits by subinfeudation was forbidden by the Provisions of Westminster, ${ }^{21}$ and this prohibition was repeated in 1267 in the Statute of Marlborough, ${ }^{22}$ which embodied the Provisions.

Greater definiteness of form in the machinery of the Court had been given in I236 by the Statute of Merton, ${ }^{23}$ which legalized what had already been the practice of allowing every freeman who owed suit to make it by his attorney. ${ }^{24}$

Thus much for the suitors in the county Court. It would take us too far afield to consider the history of the sheriff. It is sufficient to say that he was a royal official with judicial, military, financial and executive functions. ${ }^{25} \mathrm{He}$ was nominated by the King, although this right was kept by the Crown only by a struggle. ${ }^{26}$ At one time, at the close of

${ }^{17} 3^{8}$ Hen. III. Madox, History of the Exchequer, 556.

${ }^{13}$ Dialogus de Scaccario, Bk. I, Ch. VIII.

${ }^{19}$ Royal Letters, II, 394.

${ }^{20}$ Selden Society, Pleas in Manorial Courts, I. Introduction, p. xxv.

${ }^{21}$ Sec. 2.

$=$ Statutes of the Realm, I, Ch. IX, 2I, 22. 52 Hen. III.

$2 s$ Ibid., I, 4. 20 Hen. III.

"s Bracton's Note Book, P1. I672. 9 Hen. III.

${ }_{25}$ Pollock and Maitland, History of English Law, I, 518 et seq.

so Stubbs, Constitutional History, II, 21\%. 
the period under discussion, the county Court claimed the right of electing him, as an "ancient right," though they had no historic basis for such a claim. The privilege was granted in 1300 , but was revoked in I3II.

The time of meeting of the county Court brings us to a point where we have little evidence upon which to base theories. According to the Leges Henrici Primi the Court was held twice a year. In the confirmation of the Great Charter by Henry III. in $1217,{ }^{27}$ Art. 42 , it is ordered that the sheriff's Tourn be held not oftener than twice a year and that the county Court meet not more than once a month, or less frequently where such had been the custom. Stubbs hazards several hypotheses which might account for so great a multiplication of the Courts in such a comparatively short time; the sheriffs might have been abusing their power of summons in order to get the fines; the increase of business under the new system of writs might have involved short and frequent terms; the necessity might have arisen for deciding cases between hundred and hundred; there might have been a greater number of meetings for petty suitors, great cases having been withdrawn to the King's Court.

Pollock and Maitland ${ }^{28}$ offer a solution of the problem by picturing instead of a sixfold multiplication of the burden of suit, two kinds of Courts, full and intermediate, the latter attended by a smaller group of suitors. They find this theory borne out by the entries in the Hundred Rolls, where the suitors seemed to fall into two classes-those owing suit twice a year and those bound to go month by month.

The chief function of the county Court was, of course, judicial. As a Court of Law its work was mainly in civil cases; it had original jurisdiction in personal actions; it touched the feudal jurisdiction, on the one hand, by entertaining real actions when the feudal Courts made default in justice, and the Royal Court, on the other, by initiating proceedings in criminal cases, to be tried before the itinerant justices, and by having cases sent down to it for trial by jury from the King's Court. In the sheriff's Tourn, where he acted as a judge, with powers delegated by the King,

${ }^{27}$ Statutes of the Realm, I, I7-I9.

${ }^{23}$ History of English Law, I, 525. 
proceedings in criminal cases were initiated for the justices, but minor offences were settled on the spot. We have mention of a case being dismissed from the justice's Court on the plea that it was an infraction merely of the "sheriff's peace" and so should have been settled by the county Court. ${ }^{29}$

As particular instances of the jurisdiction of the Court we find that it might entertain actions of trespass and debt, without a writ, when the goods involved did not exceed forty shillings in value. ${ }^{30}$ The Statute of Gloucester ${ }^{31}$ fixed this limit in one of its provisions. This limitation, which afterwards had such disastrous effect on the vitality of the Court, was not then so narrow, as forty shillings was a "good round sum," as may be seen from the records. ${ }^{32}$

In the matter of outlawry the county Court had the only jurisdiction. Not even the King's Court could perform it, and though the justices might order it, the ceremony of exaction and outlawry could take place only in the shiremoot, as an ancient folk right. An offender had to be summoned to five successive courts and at the fifth, if he did not appear, he might be outlawed. ${ }^{33}$ In further illustration we find that if an advowson had been given to two persons an inquest might be made in the county Court. ${ }^{34}$ It might also proceed to an inquest if the claimant in an action of dower put herself upon the county. ${ }^{35}$ The sheriff and county Court might grant leave to an essoinee to rise from his bed in case he had not been viewed by the four knights. ${ }^{36}$

The point of contact with the feudal jurisdiction, as has been said, was in real actions. ${ }^{37}$ Such an action, brought by a writ of right, had to be brought first to the court of the lord of whom the plaintiff held, otherwise the proceedings fell to the ground. If, however, the lord delayed giving satisfaction longer than three weeks, or if he had no Court,

\footnotetext{
Selden Society, Select Pleas of the Crown, Pl. 2I, p. 8.

${ }^{20}$ Britton (Nichols), I, 155.

"Statutes of the Realm, I, 48 , c. viii. 6 Ed., I.

22 Rotuli Parliamentorum, I, 228.

.23 Selden Society, Court Baron, p. 85.

"Bracton, VI, I33 (f. 397).

${ }^{35}$ Ibid., IV, 585 (f. 31 $\left.3 \mathrm{~b}\right)$.

${ }^{36}$ Ibid., V, 303 (f. 356).

${ }^{37}$ Britton (Nichols), II, 326-336.
} 
or if his Court was wanting in authority, by reason of the tenant's having put himself upon the Grand Assize, or if the lord had not power to send four knights to judge of the validity of an essoin, then the plaintiff might complain to the sheriff. He then produced his writ in the full county Court and, by award of the suitors, the bailiff or other officer went with him to the Court or mansion of the lord, or if he had neither, to the land itself, and took his oath that the lord had failed to do him right. It was not sufficient to prove that the lord's Court had failed in justice, the lord himself must have been the offender, as the writ was directed to him. After this preliminary proceeding the trial began in the county Court. The lord was at liberty to come into the Court and show that the plaintiff had misinformed. the sheriff, if he came before any proceedings had been begun; but, says Britton, his jurisdiction could not be reclaimed "if the least spark of a proceeding" in the county Court could be discerned. This gave the utmost facility for evading the jurisdiction of the lords, most of whom were willing, in practice, to waive it in this particular, as little profit accrued from holding such pleas. ${ }^{38}$

Viewing the connection of the county with the Royal Courts we find that the actions described above might be removed by a writ of "Pone" from the county to the King's Court in several ways. If it were at the instance of the plaintiff no cause need be assigned, but if at the request of the tenant, the cause had to be stated in the writ and sworn to by two conjurors. Sometimes cases were removed by necessity, for instance, if the plaintiff were privileged, as a Knight Templar, or if matters were introduced over which the county had no jurisdiction. At other times the ignorance of the suitors of the county was reason for removal, or kinship of the tenant to the sheriff might be alleged.

The county Court was a Court of record only under certain circumstances, only the King's Court having this power in all cases. "Record of Court," as understood at this time, ${ }^{39}$ was simply the power of hearing testimony, which was originally made orally, and so continued to be for the

ss Hengham Magna, c. 3, p. Ir.

${ }^{39}$ Palgrave, I, I46, I47. 
county Court. The parchment roll became the "record" only by process of time, the justices or knights making it in person at first. Some of the particular cases in which the county Court had a record may be enumerated. Bracton says" it had a record of public acts "which ought to be performed with solemnity," such as enjoining persons by summons to appear at the King's Court; in cases in which a "view" was given the claimant record might be made.41 When the Court entertained the accusation of any plaintiff upon an "approver's" evidence a record should be made and sent to the King's Court by four knights, ${ }^{42}$ and in case of a duel actually waged the Court's record should be taken.

The link between the royal jurisdiction and that of the shiremoot or county Court was the visits of the itinerant justices. The circuits begun by Henry I. were continued by Henry II. and were more fully defined in II 66 by the Assize of Clarendon, ${ }^{43}$ which added important instructions and further defined the position and function of the county Court, ordering that every one come into that assembly and take the oath prescribed for preserving the peace. In I2I 5 the Great Charter promised that two justices, assisted by four knights, elected by the county, should hold the Assizes of Mort d'ancestor, Novel Disseisin and Darein Presentment, four times a year. The Charter of I2I7 changed this to once a year. Besides these sessions, every seven years there was an especially full meeting ${ }^{44}$ of the county Court to meet the justices in eyre, who held all the recognized pleas of the Crown ${ }^{45}$ as they had done since Henry I.'s time. "Twelve faithful and lawful men" were chosen by a method of co-optation, ${ }^{46}$ their names were registered, and then the prisoners charged with larceny, murder, etc., were brought before the justices. ${ }^{47}$ Before them came also any guilty clerk $^{48}$ who might have been attached by the county, but

43 Bracton, V, I45 (f. 336).

${ }^{21}$ Ibid., V, 487 (f. $379 \mathrm{~b}$ ).

\$2 Ibid., II, 535 (f. I53b).

${ }^{43}$ Stubbs, Select Charters, p. 137-I39.

"Stubbs, Select Charters, 358; also Royal Letters, I, 395.

s Hoveden, III, 263.

"Ibid., III, 262 .

"Selden Society, Court Baron, pp. 90, 9I.

"Select Pleas of the Crown, Pl. 160, p. 103. 
had been delivered to the Bishop, under penalty of $£$ Ioo to produce him before the justices. The clergy complained bitterly ${ }^{49}$ of this mode of procedure, as a clerk might remain in prison five or six years, as the Bishop dared not let him go before the justices in eyre had made their round.

Examples of the methods of pleading, the part of the sheriff and the part of the jury in these sessions may be found by reference to the Selden Society Publication, "Select Pleas of the Crown," ‘0 and Bracton's "Note Book;"'b1 and an interesting account of a meeting of a regular county Court is translated by Pollock and Maitland from the "Note Book."52

The extra judicial functions of the county Court are classified by Stubbs under the head of police, military, remedial, fiscal and electoral.

Originating out of the Anglo-Saxon Watch and Ward and renewed and enforced by the Conqueror and his successors $^{53}$ a militia, disciplined by the conservators of the peace, was gradually improved and engrafted upon the political constitution of the State ${ }^{54}$ and formed a part of the police system. The writs for the conservation of the peace, directing the taking of the oath and the pursuit of malefactors were proclaimed in full county Court, ${ }^{55}$ and in 1253 the sheriffs were ordered ${ }^{56}$ to summon all the knights and freeholders of their counties, four men with the reeve from each township and twelve burgesses from each borough to receive and execute the royal order. Those knights of the county who were to assist in maintaining the peace were sometimes "assigned," as in I253 and I264, and sometimes elected by the county as were the "custos pacis" of 1278 , the conservators for keeping the Statute of Winchester, ${ }^{57}$ and the coroners.

${ }^{13}$ Matthew Paris, VI, 355, 356 .

${ }^{30}$ Pleas, 6, 8, 38, 47, 60, 88, I06, I21, I26, I53, I60, I71, I72.

${ }^{51}$ Pleas, 40, 212, 445, 955, I0I9, I130, I412, I436, I672, I730.

${ }^{63}$ Hist. of English Law, I, 536.

${ }^{63}$ Palgrave, I, 304.

${ }^{54}$ Select Charters, pp. I43, 263, 362, 370, 411, 473.

${ }^{6}$ Stubbs, Constitutional History, II, 219.

Select Charters, p. 374.

${ }^{57}$ Rot. Parl., I, 389-391. 
Stubbs mentions no other medium for the proclamation of new laws and orders than the county Court, but it would seem that this body was used for this purpose merely as a place where many people could be reached rather than as a special administrative body. In I205 John ordered that the sheriff make his proclamation for levying a force "through your whole bailiwick and in markets and fairs and elsewhere," 58 and in the Petition of the Barons in 1258, , Art. I9, we find mention of markets as a medium of communication. The Statute of Winchester, ${ }^{60} \mathrm{Sec}$. I, provides that "cries shall be made in all counties, hundreds, markets, fairs and all other places where great resort of people is."

The military force of the kingdom falls into three divisions, the lords and their armed vassals, the minor tenants in chief and the body of freemen, the two latter of which were under the military direction of the sheriff, who retained his place in every change of military organization. When the military array of the shire for the purpose of defence was held, all the knights and freeholders were bound to attend in person; each borough answered by twelve burgesses and the four men and the reeve appeared for the villienage of their respective communities. It has been said that "convened for military purposes these musters were composed of the members who attended the judicial assemblies of the shire." Modifying this statement by the conclusion already reached concerning the attendance upon the shiremoots we may concede the idea of the shire in the two capacities, but the query is, "What part had the county Court, as such, in this military business?" Hastily glancing over some of the most important measures of military organization of the century we see the following: In 1205 John gave the order referred to above, but made no special mention of the county Court. In I223 Henry III. directed the sheriffs to impose the oath on those who had been "sworn to arms" in the time of John, but nothing is said of the county Court; nor is it mentioned in I23 I, when the sheriffs are ordered to furnish a fixed contingent, to be provided

ss Select Charters, $28 \mathrm{r}$.

${ }^{3}$ Ibid., 385 .

"Ibid., 473 . 
from the men of the county sworn under the Assize of Arms. In I282 the "Commissioners of Array" were instituted, but their selection was left entirely in the hands of the sheriff. In I297 the sheriffs were ordered to inform all who had twenty librates or more to prepare with arms to follow the King, but how or where he should give the notice is not mentioned. From this summary we may conclude that while the Court was probably the medium of communication its part, as a Court, was very small in military affairs.

The fiscal business of the shire was closely connected with the county Court through the practice of assessing and collecting taxes by chosen juries. The Assize of $\mathrm{Arms}^{61}$ in I $8 \mathrm{I}$ recognized "jury recognition" for taxation and in II98 Richard collected a carucage ${ }^{62}$ by special commissioners assisted by the sheriff and knights "elected for this." The following is a brief summary of the principal points bearing on this phase of the Court: In $1219^{63}$ two knights were appointed in each county to collect the amercements. In 1220 the sheriffs were ordered to have two knights chosen in full county Court to take part in the assessment and collection of a carucage. In I225 the knights elected for the management of the Fifteenth were chosen "by all the knights" of their county, but presumably it was done in the Court. In I232 there occurred the collection of the Fortieth. It was said, in the writ, to have been granted by "archbishops, bishops, abbots, priors, clergy, earls, barones, freeholders and villiens." Stubbs says in a note to the writ :64 "If these words are to be understood literally, the freeholders and villiens must have been consulted in the shiremoots, or else the lords must have been supposed to represent their own villien tenants in the 'Commune Consilium' as is the case in I237," when the Confirmation of the Charters was given.

The use of elected knights was continued under Edward I. and directions for the purpose were promulgated in the county Courts. In I275 the sheriffs of London and Gloucestershire were ordered to have the county elect two

\footnotetext{
' Hoveden, II, 26r, § 9.

I Ibid., IV, 46.

Royal Letters, I, 28.

" Select Charters, p. 360.
} 
men as subcollectors of customs on wool. Illustrations of the position of the county Court in regard to aid are given in the action of the Court of Yorkshire, in which, in I220, the stewards refused to grant an aid, as their lords had not been consulted, ${ }^{65}$ and in that of the Court of Worcester, which refused to pay the illegal exaction of the Eighth in I297.68

The next phase to be observed is the part taken by the Court in the remedial measures which form so large a part of the political history of the century. ${ }^{67}$ As in the fiscal business, so in this, the agency of the counties is employed, generally by means of elected representatives. In I2I 5 John ordered twelve knights to be chosen at the next county Court to inquire into evil customs, according to Article 48 of the Great Charter. In I222 two knights were sent up from Wiltshire to lay the forest liberties before the King. In I226 Henry III. ordered the sheriffs to have the county elect four knights to settle a dispute concerning the administration of the counties. In $125^{8}$ four knights brought up the complaints of the shires to the October Parliament. In I259 four knights were chosen to watch the sheriffs in each shire, ${ }^{68}$ and in 1297 four knights, elected by the county, were summoned to the national council to receive copies of the Confirmation of the Charters. From this review it may be inferred that the counties had the liberty of approaching the King, as communities, and $\mathrm{Madox}^{69}$ gives examples of petitions and negotiations for privileges by the counties.

The last function of the Court to be considered is the electoral, with special reference to knights of Parliament. Stubbs $^{70}$ bases these parliamentary elections on the evidence of the records, on the analogies of representative usage, and on the testimony of later facts. He points out that the institution of electing representatives for local purposes was in active operation for nearly eighty years before such representatives were summoned to Parliament; that these

\footnotetext{
${ }^{e s}$ Royal Letters, I, I5I.

${ }^{2}$ Stubbs, Constitutiona1 History, II, 226.

"Ibid., II, 222.

"s Ann. Burton, 477.

"Madox, History of the Exchequer, 283, 288.

${ }^{70}$ Stubbs, Const. Hist., II, 237.
} 
earlier elections were made in the full county Court and that the writs ordering the parliamentary elections contained nothing to restrict the liberty before exercised. We have already seen the most striking instances of such elections. Besides these, in I264 the knights chosen for Simon de Montfort's first Parliament" ${ }^{71}$ were elected "per assensum ejusdem comitatus." The writ for the Parliament of $1275^{72}$ provided that the two knights be elected in the "full court" with "the consent of the county." In I282, I290, I294 and I295 the elections were to be by the county and the returns of the sheriffs which are extant show that the knights were chosen by this body, as were the coroners, verderers and conservators.

We may say briefly in conclusion that in the thirteenth century the county Court was an organization with both judicial and administrative functions, differing largely in different parts of England in minor customs and methods of procedure, but approaching uniformity of action through the influence of the sheriffs, whose touch with the central government was immediate.

Lolabel House,

Fellow in American History, University of Pennsylvania.

"Select Charters, 4I2.

${ }^{72}$ Stubbs, Const. Hist., II, 234. 